\title{
Nutritional requirement of digestible threonine for brown-egg laying hens from 50 to 66 weeks of age
}

\author{
Exigência nutricional de treonina digestível para poedeiras \\ semipesadas de 50 a 66 semanas de idade
}

\author{
Ricardo Vianna Nunes ${ }^{1}$; Márcia Antonia Bartolomeu Agustini²; \\ Sabrina Endo Takahashi ${ }^{3}$; Alice Eiko Murakami ${ }^{4}$; Cleverson de Souza ${ }^{5 *}$; \\ Sandra Elisa Schneiders ${ }^{6}$; Clauber Polese ${ }^{6}$
}

\begin{abstract}
The dietary requirement of threonine was determined for brown laying hens in the period 50-66 weeks of age, based on performance parameters and quality of eggs. For this we used 150 laying Shaver Brown hens distributed in a completely randomized design with five treatments $(0.460 ; 0.490 ; 0.520 ; 0.550$ and $0.580 \%$ ) of digestible threonine, six replications and five birds each. The digestible threonine levels did not affect ( $>0.05$ ) feed intake, egg production, egg weight, egg mass or feed conversion $\mathrm{kg} \mathrm{kg}^{-1}$, but presented a quadratic effect $(\mathrm{p}<0.05)$ on feed conversion dozen $\mathrm{kg}^{-1}$, where the lower conversion was obtained with a supply of $0.521 \%$ threonine in the diet. There was no effect of dietary digestible threonine levels $(p>0.05)$ on the yolk and albumen index, specific gravity, yolk percentage, thickness or shell weight per surface area, since the variable Haugh unit displayed linear behavior $(p<0.05)$ and increased with increasing levels of dietary threonine. The percentage of albumen and shell presented a quadratic effect $(\mathrm{p}<0.05)$ according to the dietary levels of threonine, and the best levels of these variables were obtained with a supply of $0.520 \%$ and $0.521 \%$ digestible threonine in the diet. The dietary requirement of threonine for laying hens, aged between 50 and 66 weeks, based on converting food $\mathrm{kg} \mathrm{kg}^{-1}$, percentage of albumen and shell is $0.521 \%$
\end{abstract}

Key words: Digestible amino acid, laying hens, performance, egg quality

\section{Resumo}

A exigência dietética de treonina digestível foi determinada para poedeiras comerciais semipesadas no período de 50 a 66 semanas de idade, com base nos parâmetros de desempenho produtivo e de qualidade de ovos. Para isso foram utilizadas 150 poedeiras semipesadas da linhagem Shaver Brown distribuídas em um delineamento inteiramente casualizado com 5 tratamentos $(0,460 ; 0,490 ; 0,520$; 0,550 ; e $0,580 \%$ ) de treonina digestível), seis repetições e cinco aves por unidade experimental. Os

1 Prof. Dr. em Zootecnia, Universidade Estadual do Oeste do Paraná, UNIOESTE, Marechal Cândido Rondon, PR. Brasil. E-mail: nunesrv@hotmail.com

2 Prof $f^{a}$ M.e em Zootecnia, Universidade Tecnológica Federal do Paraná, UTFPR, Medianeira, PR, Brasil. E-mail: marciaagustini@, utfpr.edu.br

3 Prof ${ }^{a}$ Dr $^{\mathrm{a}}$ em Zootecnia, Universidade Tecnológica Federal do Paraná, UTFPR, Dois Vizinhos, PR, Brasil. E-mail: sabrinaendo@ gmail.com

4 Discente do Curso de Mestrado em Zootecnia, Universidade Estadual de Maringá, UEM, Maringá, PR, Brasil. E-mail: cleversonsz@hotmail.com

5 Prof ${ }^{a}$ Dra $^{\mathrm{a}}$, em Zootecnia, UEM, Maringá, PR, Brasil. E-mail: aemurakami@uem.br

6 Discentes do Curso de Mestrado em Zootecnia, UNIOESTE, Marechal Cândido Rondon, PR, Brasil. E-mail: sandrinhaes_86@ yahoo.com.br; polesepr@yahoo.com.br

* Author for correspondence 
níveis de treonina digestível não influenciaram $(\mathrm{p}>0,05)$ o consumo de ração, produção de ovos, peso de ovos, massa de ovos e conversão alimentar $\mathrm{kg} \mathrm{kg}^{-1}$, mas apresentaram efeito quadrático $(\mathrm{p}<0,05)$ sobre a conversão alimentar $\mathrm{kg}_{\text {dúzia }}{ }^{-1}$, onde o menor valor de conversão foi obtido com o fornecimento de $0,521 \%$ de treonina digestível na dieta. Não foi observado efeito dos níveis dietéticos de treonina digestível $(\mathrm{p}>0,05)$ sobre o índice de gema e de albúmen, gravidade específica, porcentagem de gema, espessura e peso da casca por superfície de área, já a variável unidade haugh apresentou comportamento linear $(\mathrm{p}<0,05)$, aumentando com o aumento dos níveis de treonina dietéticos. A porcentagem de albúmen e casca apresentaram efeito quadrático $(\mathrm{p}<0,05)$ em função dos níveis dietéticos de treonina digestível, sendo que os melhores níveis dessas variáveis foram obtidos com o fornecimento de 0,520 e $0,521 \%$ de treonina digestível na dieta. A exigência dietética de treonina digestível para poedeiras semipesadas, com idade entre 50 e 66 semanas, baseada na conversão alimentar $\mathrm{kg} \mathrm{kg}^{-1}$, porcentagem de albúmen e casca é de $0,521 \%$

Palavras-chave: Aminoácido digestível, aves de postura, desempenho, qualidade de ovo

\section{Introduction}

With the progress made in breeding programs, laying hens are demonstrating high egg production and peak production earlier (CUPERTINO et al., 2009). We seek to harness nutrition to genetic dynamism, aiming to further improve production indices (MEDINA, 2003).

The concept of ideal protein is currently being widely used to determine the ideal amino acid profile of diets, based on the relationship between the lysine $(100 \%)$ and the other amino acids (PASTOR et al., 2013). In corn-based feed and soybean meal, threonine is the third limiting amino acid, and as the birds are not able to synthesize it there is a high requirement of this amino acid in relation to the other, since it is associated with the formation of protein and maintenance of protein turnover, helps in the formation of antibodies and is present in the gastrointestinal epithelium (KIDD; KERR, 1996). It is also used in mucin synthesis, the function of which is to protect the gastrointestinal tract (MYRIE et al., 2001), and is an important component in the feathers (KIDD, 2000).

Schmidt et al. (2010) believe the experimental evidence supporting recommendations for threonine is sparse and conflicting due to the nutritional, genetic, environmental and even the variety of methods used in the determination of nutritional requirements (HUYGHEBAERT; BUTLER, 1991).

Sá et al. (2007) recommend $0.517 \%$ of threonine for light and semi-heavy birds 34-50 weeks old, and conclude that feed conversion, production and egg mass are positively affected. Cupertino et al. (2009), however, when working with levels ranging from 0.380 to $0.511 \%$ of digestible threonine for laying hens 54-70 weeks of age, found no effect ( $p>0.05)$ on feed intake, weight or internal egg quality.

Levels of threonine amino acid should be considered in laying hen diet formulations because its excess or deficiency compromises bird performance (SCHMIDT et al., 2010). The objective of this work was thus to evaluate the nutritional levels of threonine for laying Shaver Brown hens, between 50-66 weeks of age.

\section{Materials and Methods}

The experiment was carried out in the Education and Small Animal Research Unit of the Federal Technological University of Paraná - UTFPR, Campos Dois Vizinhos - PR. 150 semi-heavy Shaver Brown laying hens were used, at 50 weeks old, with an average weight of $1857.89 \pm 87.65$ grams.

The selection and distribution of birds was performed in the experimental units according to body weight and egg production. Laying hens were organized in five treatments, of six groups with five birds each in a completely randomized design. The hens were fed ad libitum in gutter type feeders and water was supplied via nipple containers. 
During breeding, rearing and production, the birds were handled as described in the respective strain recommendations. In the production phase, the birds were housed in cages $(50 \times 40 \times 50 \mathrm{~cm})$ in a closed brick shed $(8.5 \times 20 \mathrm{~m})$ with anti-bird screens on the sides, covered with clay tiles, and foot right of $2.80 \mathrm{~m}$ high. They were submitted to a lighting program of 16 hours light, 12 hours and four natural artificial hours.
To determine the nutritional requirement of threonine, an isocaloric and isonutritive basal diet (Table 1) was formulated, estimating feed intake of $110 \mathrm{~g} / \mathrm{bird} / \mathrm{day}$, except for the levels of threonine, which were supplemented at $0.00 ; 0.027 ; 0.058$; 0.089 ; and $0.120 \%$ L-threonine $(98 \%)$ to provide the actual levels tested of $0.460 ; 0.490 ; 0.520 ; 0.550$ and $0.580 \%$ of digestible threonine. Threonine levels followed, respectively, the relationship of 61 , $65,69,73$ and $77 \%$ with lysine set at $0.750 \%$. The other nutrients in the diet met the recommendations of Rostagno et al. (2005).

Table 1. Ingredients and nutritional composition of the experimental diets.

\begin{tabular}{|c|c|c|c|c|c|}
\hline \multirow[t]{2}{*}{ Ingredients } & \multicolumn{5}{|c|}{ Threonine level (g/kg) } \\
\hline & 4.60 & 4.90 & 5.20 & 5.50 & 5.80 \\
\hline Corn grain & 660.86 & 658.28 & 659.33 & 660.45 & 661.41 \\
\hline Soybean Meal (45\%) & 193.65 & 196.00 & 195.41 & 194.80 & 194.20 \\
\hline Soybean oil & 19.91 & 19.91 & 19.06 & 18.33 & 17.59 \\
\hline Dicalcium phosphate & 21.23 & 21.23 & 21.21 & 21.10 & 21.20 \\
\hline Limestone & 94.11 & 94.11 & 94.11 & 94.11 & 94.07 \\
\hline Livestock salt & 3.50 & 3.50 & 3.50 & 3.50 & 3.50 \\
\hline L- Threonine (98\%) & 0.00 & 0.27 & 0.58 & 0.89 & 1.20 \\
\hline DL -Methionine (98\%) & 2.72 & 2.72 & 2.73 & 2.73 & 2.73 \\
\hline L- lysine. $\mathrm{HCl}(78 \%)$ & 1.55 & 1.56 & 1.57 & 1.58 & 1.59 \\
\hline L-Tryptophan (98\%) & 0.30 & 0.22 & 0.30 & 0.31 & 0.31 \\
\hline Mineral Supplement / Vitamin 1 & 2.00 & 2.00 & 2.00 & 2.00 & 2.00 \\
\hline Antioxidante $^{2}$ & 0.20 & 0.20 & 0.20 & 0.20 & 0.20 \\
\hline Total & 1000.00 & 1000.00 & 1000.00 & 1000.00 & 1000.00 \\
\hline NUTRITIONAL VALUE & & & & & \\
\hline Metabolizable energy (kcal/g) & 2.85 & 2.85 & 2.85 & 2.85 & 2.85 \\
\hline Crude protein $(\mathrm{g} / \mathrm{kg})$ & 147.7 & 148.8 & 149.0 & 149.1 & 149.2 \\
\hline Calcium $(\mathrm{g} / \mathrm{kg})$ & 4.20 & 4.20 & 4.20 & 4.19 & 4.19 \\
\hline Available Phosphorus (g/kg) & 4.8 & 4.8 & 4.8 & 4.7 & 4.8 \\
\hline Sodium $(\mathrm{g} / \mathrm{kg})$ & 1.5 & 1.5 & 1.5 & 1.5 & 1.5 \\
\hline Lysine (g/kg) & 7.5 & 7.5 & 7.5 & 7.5 & 7.5 \\
\hline Met + Cys digestible $(\mathrm{g} / \mathrm{kg})$ & 6.8 & 6.8 & 6.8 & 6.8 & 6.8 \\
\hline Digestible Threonine $(\mathrm{g} / \mathrm{kg})$ & 4.6 & 4.9 & 5.2 & 5.5 & 5.8 \\
\hline Digestible Tryptophan (g/kg) & 1.7 & 1.7 & 1.7 & 1.7 & 1.7 \\
\hline Digestible Valine ( $\mathrm{g} / \mathrm{kg})$ & 6.1 & 6.1 & 6.1 & 6.1 & 6.1 \\
\hline Digestible Isoleucine (g/kg) & 5.4 & 5.4 & 5.4 & 5.4 & 5.4 \\
\hline Digestible Arginine $(\mathrm{g} / \mathrm{kg})$ & 12.4 & 12.5 & 12.5 & 12.5 & 12.5 \\
\hline
\end{tabular}

Rovimix matrix (Roche ) - Composition/kg: vit. A 3.997.500 U.I.. vit D3 2.880.000 U.I.. vit. E 7.500 U.I.. vit K3 1.500 mg. vit. B1 $750 \mathrm{mg}$. vit B2 $2.505 \mathrm{mg}$. vit B6 $1.500 \mathrm{mg}$. vit. B12 $7.500 \mathrm{mcg}$. Ác. Nicotinic 12,500 mg. Ác. pantothenic 4,005 mg . $50 \mathrm{mg}$ biotin . ác . Folic 500mg. Iron 25,000 mg. Copper 5,000 mg. Zinc 30,000 mg. Manganese 40,000 mg. Selenium $128 \mathrm{mg}$. Iodine $500 \mathrm{mg}$. Cobaldo $500 \mathrm{mg}$. Bacitracin Zinc 25,000 mg Antioxidant 15. vehicle q.s. 1,000g.

${ }^{2}$ Hidroxitolueno butilado. 
Until their 50th week of age, the birds received a conventional diet as per the nutritional recommendations of Rostagno et al. (2005), after which they proceeded to the beginning of the trial, which lasted 16 weeks and was divided into four periods of data collection, each corresponding to 28 days, with the following variables evaluated: feed consumption, feed conversion per dozen $(\mathrm{kg}$ $\left.\mathrm{dz}^{-1}\right)$ and egg mass $\left(\mathrm{kg} \mathrm{kg}^{-1}\right)$, laying rate (\%) egg weight $(\mathrm{g})$ egg mass $(\mathrm{g})$, percentage of components (shell, albumen and yolk), shell weight per unit area (PCSA), specific gravity, shell thickness, Haugh unit, yolk index and albumen index.

Egg collection was performed daily by hand in the morning (11:00 am) and afternoon (16:00), and the laying rate was calculated based on the number of eggs produced/bird/day. In the last three days of each experimental period (28 days) all the eggs in each repetition, were individually weighed to determine the average weight and egg mass, which was obtained by the production of bird day during the period by the average egg weight.

Feed intake (g/bird/day) was measured weekly by weighing the uneaten remains. In the event of mortality in the experimental unit, feed intake was corrected. Feed conversion was calculated by dividing the feed intake by production of a dozen eggs $\left(\mathrm{kg} \mathrm{dz}^{-1}\right)$ and the egg mass produced $\left(\mathrm{kg} \mathrm{kg}^{-1}\right)$ during each trial.

To determine the specific gravity, all eggs were evaluated by flotation in saline solutions with densities ranging from 1.075 to 1.095 . To determine internal quality and the physical composition of the eggs, four eggs ( $\pm 10 \%$ of average weight) were selected per experimental unit in the last three days of each period: two were used for the determination of egg components (percentage of shell, yolk and albumen) and the other two for the assessment of internal quality (Haugh unit, yolk index and albumen).

The percentage of egg components was determined by weighing the egg (whole egg weight), and then cracking, for further weighing of the yolk and eggshell. The bark was weighed after standing for 48 hours at room temperature and for 8 hours in an oven with air circulation at $65{ }^{\circ} \mathrm{C}$. The weight of the albumen was determined by subtracting the integrity of the egg weight, less the weight of the yolk and shell.

Haugh units were determined using the method described by Haugh (1937), and the contents of albumen and yolk were obtained by averaging the diameters of albumen and yolk using a digital caliper, following the methodology described by Snyder (1961). The skin thickness was measured at two different points on the same meridian, using a digital micrometer to an accuracy of $0.001 \mathrm{~mm}$. The shell weight per unit surface area (SWUSA) was calculated using the methodology adapted from Rodrigues et al. (1996).

The requirements of threonine were estimated using the variables of productive performance and egg quality, by analysis of variance (ANOVA) and subsequently polynomial regression analysis. When more than one equation presented significance, the equation to be used was selected according to the higher value of the coefficient of determination $\mathrm{R}^{2}$, indicating the adjustment data for the proposed model: the greater the value the better the adjustment coefficient data as shown through the program SAEG - Statistics and Analysis System for Gene (UFV, 1999).

\section{Results and Discussion}

There was no effect $(\mathrm{p}>0.05)$ of digestible threonine levels on feed intake, egg production, average egg weight, egg mass, feed conversion per egg mass and feed intake (Table 2) per dozen. This result is similar to that found by Sá et al. (2007), who worked with laying Lohmann Brown hens of 34 to 50 weeks old, and found no effect of digestible threonine levels on feed intake.

It was observed that the lowest level of threonine 
used in the diet was sufficient to meet the needs of the birds for appetite and concentration of amino acids in the blood, so that feed intake did not need to be varied, since according to Andriguetto (2003), an amino acidic imbalance in the diet can cause specific changes in the concentration of amino acids in the blood, affecting the appetite of birds.

The threonine level used in the feed did not affect $(p>0.05)$ egg production (Table 2), which was 84.61 , showing that a diet containing $4.6 \mathrm{~g} \mathrm{~kg}^{-1}$ of threonine meets the nutritional requirements of laying, with no deficiency or excess of amino acids.

These results are similar to those of Valério et al. (2000), who obtained an average $85.48 \%$ for the production of eggs by Lohmann Brown hens of 21 weeks of age. Sá et al. (2007), however, observed a positive effect from digestible threonine levels, with semi-heavy laying Lohmann Brown hens 3450 weeks old. Alvarez (1998) suggested 0.744\% digestible threonine as the level required for higher egg production (91.72\%) for 33-41 week old laying hens.

There was no effect $(\mathrm{p}>0.05)$ of digestible threonine levels on egg weight (Table 2), in agreement with the results obtained by Huyghebaert and Butler (1991), Ishibashi et al. (1998), Camps (2001), Faria et al. (2001) and Sá et al. (2007).

Egg weight values for the laying hens in this experiment were higher than those cited in the lineage manuals, which refer to eggs of 63.2 to $64.0 \mathrm{~g}$. In this work, the average egg weight was $65.88 \mathrm{~g}$, with levels ranging from 4.6 to $5.8 \mathrm{~g} / \mathrm{kg}$ of digestible threonine. Alvarez (1998) indicates $0.744 \%$ to $0.775 \%$ as the best threonine inclusion levels for variable egg weight, resulting in brown birds of $62.25 \mathrm{~g}$ at 33 and 44 weeks old. This difference may be attributed to the age of the birds used in the experiment, as egg weight increases with the age of the laying.

The production of variable egg mass (Table 2) did not influence the levels of digestible dietary threonine $(p>0.05)$, in disagreement with Sá et al. (2007), who found a quadratic effect when working with levels ranging from 4.1 to $5.5 \mathrm{~g} \mathrm{~kg}$ ${ }^{-1}$ of threonine in the diet for laying Lohmann and Lohmann Brown hens.

The average egg mass $(55.76 \mathrm{~g} / \mathrm{bird} /$ day) was higher than that observed by Valério et al. (2000), who found that $40.4 \mathrm{~g} / \mathrm{bird} /$ day used threonine levels ranging from 0.510 to $0.635 \%$, and, Alvarez (1998) who reported averages of $57.09 \mathrm{~g} 56.51 \mathrm{~g}$ variable egg mass, using 0.744 and $0.775 \%$ of digestible threonine in diets for laying.

It is important to note, however, that the birds used in this study were older (50 to 66 weeks) than the birds used for the work of Alvarez (1998) and Valério et al. (2000), contradicting the claim of Grobas et al. (1999), that older birds have lower egg mass. In this context, the diet containing $4.6 \mathrm{~g} \mathrm{~kg}^{-1}$ of threonine met the nutritional requirements of laying Shaver Brown hens for variable egg mass, and also exceeded the amount shown in the lineage manual (47.8g/ave/dia).

Feed conversion (FD) was not affected $(\mathrm{p}<0.05)$ by levels of threonine in the diet (Table 2), in agreement with the results obtained by Valério et al. (2000), who found no effect for dietary levels of threonine $(0.510$ to $0.635 \%)$ on the feed conversion of laying Lohmann Brown hens. Several authors (HUYGHEBAERT; BUTLER, 1991; ISHIBASHI et al., 1998) found that digestible threonine levels in the diet improved feed conversion.

Nutritional requirements for the variable feed conversion per dozen eggs (CADZ) were estimated by polynomial analysis. A $5.21 \mathrm{~g} \mathrm{~kg}^{-1}$ level of threonine was estimated, corresponding to a daily intake of $601 \mathrm{mg} / \mathrm{bird} /$ day, with average feed consumption of $115.76 \mathrm{~g} / \mathrm{bird} /$ day. This result corroborates Cupertino et al. (2009), who used Lohmann Brown hens and levels ranging from 0.380 to $0.511 \%$ of threonine. Teixeira et al. (2005), however, used levels ranging from 0.37 to $0.79 \%$ threonine for laying hens 44 weeks old, and found no effect on feed conversion per dozen eggs. 
The CADZ variable was higher in this experiment than recommended by Sá et al. (2007), who concluded that the daily threonine requirement to obtain better feed conversion per dozen laying hens, was $5.05 \mathrm{~g} / \mathrm{kg}$ of digestible threonine, corresponding to $562 \mathrm{mg}$ of threonine for Lohmann Brown birds from 34 to 50 weeks of age.

The results for the components of the eggs (yolk percentages, bark and albumen shell thickness and shell weight per unit surface area) are shown in Table 3.

The levels of threonine in the diet did not affect ( $p>0.05$ ) internal egg quality (YI, IA and UH), in agreement with the results obtained by Valério et al. (2000) who, when using increasing levels of threonine in the diet, found no improvement in Haugh units. This parameter, (UH) directly relates egg weight ( $\mathrm{g}$ ) to albumen height ( $\mathrm{mm}$ ).

When working with laying hens 34-50 weeks old Sá et al. (2007) did not find any influence of digestible threonine levels on the contents of yolk and albumen. The Haugh units showed a positive quadratic effect with increasing levels of dietary digestible threonine, and $4.78 \mathrm{~g} / \mathrm{kg}$ was suggested as optimal. At levels of 5.15 and $5.50 \mathrm{~g} \mathrm{~kg}^{-1}$, the authors found no differences in the Haugh units.

It must be borne in mind that the storage time of the eggs, the age of the hens (SILVERSIDES; SCOTT, 2001) (FARIA et al., 2001), temperature in the production hall and variation in the appliances used to determine the height and diameter of the yolk and albumen, can contribute to variations in results, affecting the relationship between experimental results (ROCHA et al., 2009).

The digestible threonine levels in the diet did not affect $(p>0.05)$ the average density of eggs (specific gravity), demonstrating that the levels had not damaged the external egg quality (bark). It is noteworthy that anti-nutritional factors, temperature, handling, and age of the birds, among other things, could affect the specific gravity (YANNAKOPOULOS; TSERVENI-GOUSI, 1986).

There was no effect $(p>0.05)$ in the levels of threonine for the variables of percentage yolk shell thickness and shell weight per unit surface area (Table $3)$. The percentage of bark demonstrated quadratic behavior, this may be linked to an imbalance in amino acid intake, resulting in malabsorption of nutrients essential for the formation of the egg shell (FIGUEIREDO et al., 2012).

There was no effect of digestible threonine levels for the variables percentage of yolk and shell thickness and shell weight per unit surface area (Table 3). The percentage of eggshell was on average $9.44 \%$, higher than that found by Matos et al. (2009).

The levels of threonine quadratically influenced $(p<0.05)$ the percentage of albumen in the eggs of laying hens. The equation $\mathrm{Y}=123,707$ 22,9384 Threodig $+2,20503$ Threodig $^{2}$ estimated the maximum percentage of albumen as $64.05 \%$, with a level of dietary digestible threonine estimated at $0.520 \%$. This result disagrees with Cupertino et al. (2009) and Schmidt et al. (2010), who found no effect from digestible threonine levels in the diet on the variable percentage of albumen in laying Lohmann Brown hens. A factor that may explain the decrease in the percentage of albumen is the protein content of the diet. Penz Júnior (1990) found that $13-14 \%$ crude protein in feed for laying helps to decrease the albumen, which is not minimized by supplementation of amino acids when compared to diets containing $16 \%$ crude protein. 


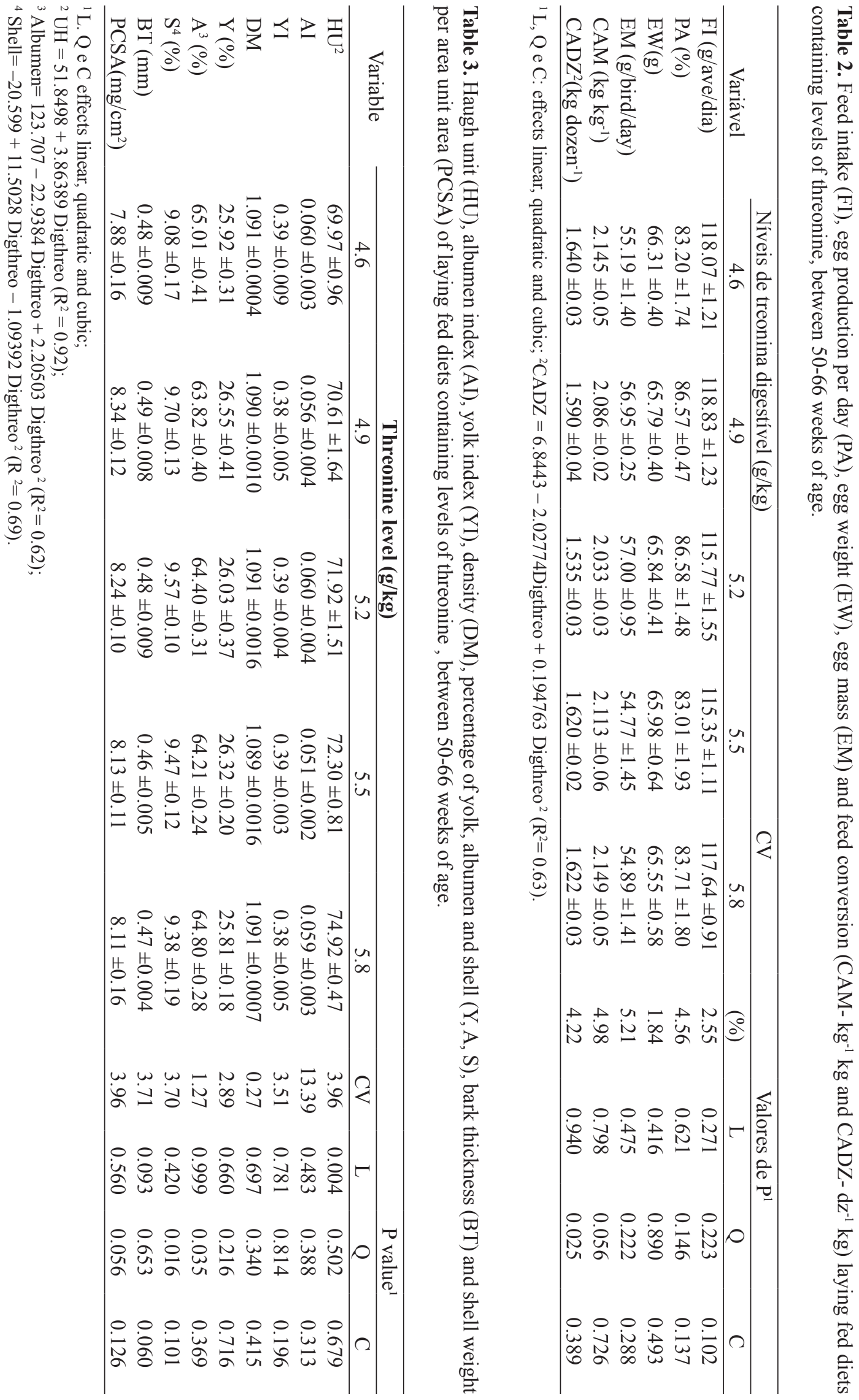




\section{Conclusion}

The dietary requirement of threonine for laying hens, aged between 50 and 66 weeks, based on converting food $\mathrm{kg} \mathrm{kg}^{-1}$, and percentage of albumen and shell, is $0.521 \%$.

\section{References}

ALVAREZ, A. V. E. Efecto del nivel de L-treonina en dietas para gallinas de postura comercial durante el período de la semana 33 a la 41 de edad. 1998. Monografia (Trabalho de Conclusão de Curso em Zootecnia) - Univesidad de San Carlos de Guatemala, San Carlos.

ANDRIGUETTO, J. M. Nutrição animal. São Paulo: Nobel, 2003. v. 1, v. 2, 390 p.

CAMPS, D. M. Dietas bajas en proteínas con suplementación de treonina y triptofano en la alimentación de ponedoras comerciales. Revista Cubana de Ciencia Avícola, La Habana, v. 25, n. 2, p. 131-136, 2001.

CUPERTINO, E. S.; GOMES, P. C.; ROSTAGNO, H. S.; DONZELE, J, L.; SCHMIDT, M.; CARVALHO MELO, H. H. Exigência nutricional de metionina+cistina para galinhas poedeiras de 54 a 70 semanas de idade. Revista Brasileira de Zootecnia, Viçosa, MG, v. 38, n. 7, p. 12381246, 2009.

FARIA, D. E.; JUNQUEIRA, O. M.; SOUZA, P. A.; TITTO, E. A. L. Desempenho, temperatura corporal e qualidade de ovos de poedeiras alimentadas com vitamina $\mathrm{D}$ e $\mathrm{C}$ em três ambientes. Revista Brasileira de Ciência Avícola, Campinas, v. 3, n. 1, p. 49-56, 2001.

FIGUEIREDO, G.; BERTECHINI, A.; FASSANI, E.; RODRIGUES, P. B.; BRITO, J. Á.; CASTRO, S. Performance and egg quality of laying hens fed with dietary levels of digestible lysine and threonine. Arquivo Brasileiro de Medicina Veterinária e Zootecnia, Belo Horizonte, v. 64, n. 3, p. 743-750, 2012.

GROBAS, S.; MENDEZ, J.; DE BLAS, C.; MATEOS, G. G. Laying hen productivity as affected by energy, supplemental fat, and linoleic acid concentration of the diet. Poultry Science, College Station, v. 78, n. 11, p. 1542-1551, 1999.

HAUGH, R. R. The haugh unit for measuring egg quality. United States Egg and Poultry Magazine, Chicago, v. 4, n.1, p. 552-555, 1937.

HUYGHEBAERT, G.; BUTLER, E. A. Optimun threonine requirements of laying hens. British Poultry Science, Merelbeke, v. 32, n. 3, p. 575-582, 1991.
ISHIBASHI, T.; OGAWA, Y.; ITOH, T.; FUJIMURA, S.; KOIDE, K.; WATANABE, R. Threonine requeriment of laying hens. Poultry Science, Mississipi, v. 77, n. 7, p. 998-1002, 1998.

KIDD, M. T. Nutritional considerations concerning threonine in broilers. World's Poultry Science Journal, Londres, v. 56, n. 2, p. 139-151, 2000.

KIDD, M. T.; KERR, B. J. L-threonine for poultry: a review. The Journal of Applied Poultry Research, College Station, v. 5, n. 4, p. 358-367, 1996.

MATOS, M.; LEANDRO, M. N.; CARVALHO, F. B.; STRINGHINI, J. H.; CAFÉ, M. B.; LOPES, K. L. Níveis de lisina e treonina digestíveis na ração de poedeiras comerciais sobre a qualidade de ovos. Animal Sciences, Maringá, v. 31, n. 1, p. 25-29, 2009.

MEDINA, G. J. R. Avanços na nutrição da poedeira moderna. Campinas: CNBA, 2003. $21 \mathrm{p}$.

MYRIE, S. B.; BERTOLO, R. S.; SAURER, W.; BALL, R. O. Threonine requeriment and availability are affected by feed that stimulate gut mucin. Advances in Pork Production, Edmonton, v. 12, abstract n. 23, 2001.

PASTOR, A.; WECKE, C.; LIEBERT, F. Assessing the age-dependent optimal dietary branched-chain amino acid ratio in growing chicken by application of a nonlinear modeling procedure. Poultry science, College Station, v. 92, n. 12, p. 3184-3195, dez. 2013.

PENZ JÚNIOR; A. M. Exigências de aminoácidos das poedeiras. In: CICLO DE CONFERÊNCIAS DA ASSOCIAÇÃO DOS MÉDICOS VETERINÁRIOS, 2., 1990, Porto Alegre. Anais... Porto Alegre: APINCO, 1990. p. 88-110.

ROCHA, T. C.; GOMES, P. C.; DONZELE, J. L. Níveis de lisina digestível em rações para poedeiras no período de 24 a 40 semanas de idade. Revista Brasileira de Zootecnia, Viçosa, MG, v. 38, n. 9, p. 1726-1731, 2009.

RODRIGUES, P. B.; BERTECHINI, A. G.; OLIVEIRA, B. L.; TEIXEIRA, A. S.; OLIVEIRA, A. I. G. Fatores nutricionais que influenciam a qualidade do ovo no segundo ciclo de produção. I. Níveis de aminoácidos sulfurosos totais. Revista Brasileira de Zootecnia, Viçosa, MG, v. 25, n. 2, p.249-260, 1996.

ROSTAGNO, H. S.; ALBINO, L. F. T.; DONZELE, J. L.; GOMES, P. C.; OLIVEIRA, R. F.; LOPES, D. C.; FERREIRA, A. S.; BARRETO, S. L. T. Tabelas brasileiras para suínos e aves: composição de alimentos e exigências nutricionais. 2. ed. Viçosa, MG: Universidade Federal de Viçosa, 2005. 186 p. 
SÁ, L. M.; GOMES, P. C.; CECON, P. R.; ROSTAGNO, H. S.; D'AGOSTINE, P. Exigências nutricional de treonina digestível para galinhas poedeiras no período de 34 a 50 semanas de idade. Revista Brasileira de Zootecnia, Viçosa, MG, v. 36, n. 6, p. 1846-1856, 2007.

SCHMIDT, M.; ROSTAGNO, H. S.; NUNES, R. V.; PUPA, J. M. R.; GOMES, P. C. Níveis nutricionais de lisina, de metionina + cistina e de treonina digestíveis para galinhas poedeiras no $2^{\circ}$ ciclo de produção. Revista Brasileira de Zootecnia, Viçosa, MG, v. 39, n. 5, p. 10991104, 2010.

SILVERSIDES, F. G.; SCOTT, T. A. The relationships among measures of egg albumen height, $\mathrm{pH}$ and whipping volume. Poultry Science, College Station, v. 80, n. 8, p. 1240-1245, 2001.

SNYDER, E. S. Eggs, the production, the identification and retention of quality in eggs. Guelph: Ontario Agricultural College, $1961.90 \mathrm{p}$.
TEIXEIRA, E. N. M.; VILAR DA SILVA, J. H.; SILVA, E. L. Exigência de treonina digestível para poedeiras leves e semipesada. In: CONFERÊNCIA APINCO DE CIÊNCIA E TECNOLOGIA AVÍCOLAS, 2005, Santos. Anais... Santos: FACTA, 2005. p. 131.

UNIVERSIDADE FEDERAL DE VIÇOSA - UFV. SAEG - Sistema para análises estatísticas e genéticas. Viçosa, MG: 1999. 59 p. (Manual do usuário).

VALÉRIO, S. R.; SOARES, P. R.; ROSTAGNO, H. S.; ALMEIDA E SILVA, M.; ALBINO, L. F. T.; LANA, G. R. Q.; GOULART, C. C.; KILL, J. L. Determinação da exigência nutricional de treonina para poedeiras leves e semipesadas. Revista Brasileira de Zootecnia, Viçosa, MG, v. 29, n. 2, p. 518-524, 2000.

YANNAKOPOULOS, A. L.; TSERVENI-GOUSI, A. S. Quality characteristics of quail eggs. British Poultry Science, Merelbeke, v. 27, n. 2, p. 171-176, 1986. 
